\title{
Exotic Ecosystem Engineers Change the Emergence of Plants from the Seed Bank of a Deciduous Forest
}

\author{
Nico Eisenhauer, ${ }^{1,4 *}$ Daniela Straube,${ }^{1}$ Edward A. Johnson, ${ }^{2,3}$ \\ Dennis Parkinson, ${ }^{2}$ and Stefan Scheu ${ }^{1,4}$
}

\begin{abstract}
${ }^{1}$ Institute of Zoology, Darmstadt University of Technology, Schnittspahnstr. 3, 64287 Darmstadt, Germany; ${ }^{2}$ Department of Biological Science, University of Calgary, 2500 University Drive NW, Calgary, Alberta T2N 1N4, Canada; ${ }^{3}$ Biogeoscience Institute, University of Calgary, 2500 University Drive NW, Calgary, Alberta T2N 1N4, Canada; ${ }^{4}$ J.F. Blumenbach Institute of Zoology and Anthropology, Georg-August-University Göttingen, Berliner Str. 28, 37073 Göttingen, Germany
\end{abstract}

\begin{abstract}
The anthropogenic spread of exotic ecosystem engineers profoundly impacts native ecosystems. Exotic earthworms were shown to alter plant community composition of the understory of deciduous forests previously devoid of earthworms. We investigated the effect of two exotic earthworm species (Lumbricus terrestris L. and Octolasion tyrtaeum Savigny) belonging to different ecological groups (anecic and endogeic) on the emergence of plants from the seed bank of a northern North American deciduous forest using the seedling emergence method. We hypothesized that (1) exotic earthworms change the seedling emergence from the plant seed bank, (2) L. terrestris increases the emergence of plant seedlings of the deeper soil layer but decreases that of the upper soil layer due to plant seed burial, and (3) O. tyrtaeum decreases plant seedling emergence due the damage of plant seeds. Indeed, exotic earthworms altered the emergence of plant seedlings from the seed bank and the functional composition of the established
\end{abstract}

plant seedlings. Surprisingly, although L. terrestris only marginally affected seedling emergence, O. tyrtaeum changed the emergence of native plant species from the seed bank considerably. In particular, the number of emerging grass and herb seedlings were increased in the presence of $O$. tyrtaeum in both soil layers. Moreover, the impacts of earthworms depended on the identity of plant functional groups; herb species benefited, whereas legumes suffered from the presence of exotic earthworms. The results highlight the strong effect of invasive belowground ecosystem engineers on aboveground ecosystem characteristics and suggest fundamental changes of ecosystems by humanspread earthworm species.

Key words: above- and belowground interactions; exotic earthworms; Lumbricus terrestris; Octolasion tyrtaeum; plant seedlings; seedling emergence; soil seed bank.
Received 16 January 2009; accepted 12 May 2009; published online 11 September 2009

Author Contributions: Designed study: NE, EAJ, DP, SS; performed research: NE, DS; analyzed data: NE; wrote the paper: NE, SS.

*Corresponding author; e-mail: eisenhauer@bio.tu-darmstadt.de

\section{INTRODUCTION}

Human alterations of Earth's ecosystems and their functions are substantial and multifaceted (Vitousek and others 1997). One major mechanism by which human activity alters ecosystem functions is 
the introduction of exotic species (Vitousek and others 1996). In particular, the spread of ecosystem engineers profoundly impacts native ecosystems (Morrison 2002; Cuddington and Hastings 2004; Anderson and Rosemond 2007).

Previous studies on species invasions primarily focussed on aboveground plant and animal species. Recently, studies on exotic earthworms showed that also belowground invaders strongly impact above- and belowground ecosystem properties (Bohlen and others 2004; Hale and others 2005, 2006, 2008; Eisenhauer and others 2007; Straube and others 2009). Invasive earthworms were shown to alter physical and chemical soil characteristics, nutrient cycling and mineralization, microbial functioning, and the density and diversity of other soil invertebrates (Bohlen and others 2004; Groffman and others 2004; Migge-Kleian and others 2006; Eisenhauer and others 2007; Straube and others 2009). Moreover, exotic earthworms were also reported to profoundly change plant community composition of the understory of deciduous forests by altering seedbed conditions (Hale and others 2005, 2006; Frelich and others 2006; Holdsworth and others 2007).
Although the native earthworm fauna of northern North America is restricted to Pacific coastal regions (McKey-Fender and Fender 1982), European earthworms have been colonizing the North American continent since European settlement (Gates 1982; Addison 2009). Currently, a variety of ecosystems are being invaded by exotic earthworms in southern Alberta (Scheu and McLean 1993; Addison 2009). Eisenhauer and others (2007) reported the recent invasion of the two exotic earthworm species, Lumbricus terrestris L. (Figure 1C) and Octolasion tyrtaeum Savigny (Figure 1D), into an aspen forest in the mountain ranges of the Rocky Mountains west of Calgary (Kananaskis Valley, Alberta). The anecic species $L$. terrestris forms vertical permanent burrows up to $2 \mathrm{~m}$ deep, consumes, accumulates and incorporates surface litter into deeper soil layers, and transports mineral soil materials to the soil surface by casting, thereby forming earthworm middens (Lee 1985; Edwards 2004). Octolasion tyrtaeum, as an endogeic species, lives in upper mineral soil layers mainly consuming soil organic matter. Both species were shown to function as keystone detritivores and ecosystem engineers (Jones and others 1994; Lavelle and others 1998; Eisenhauer and others 2007).
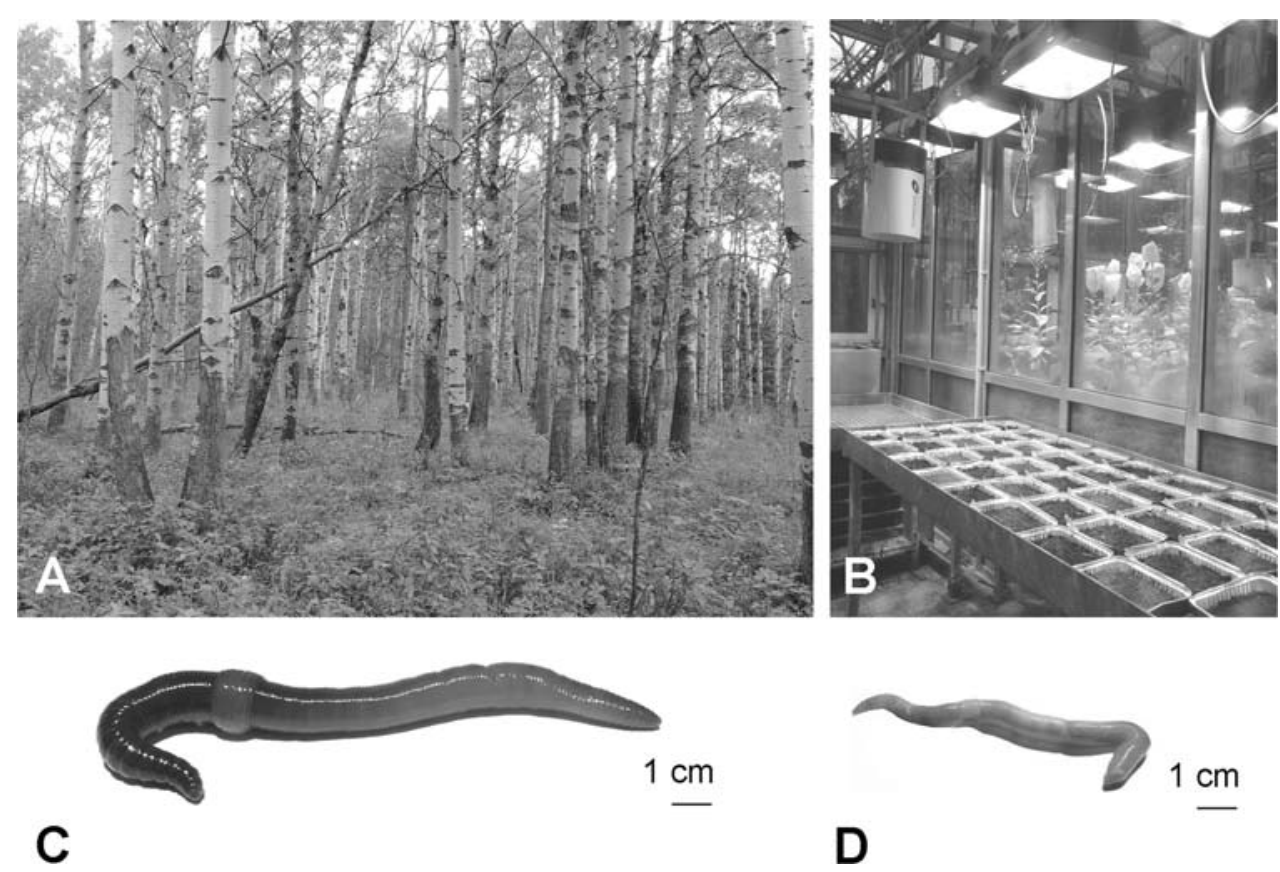

Figure 1. Photograph (A) of the studied aspen forest in southwest Alberta (Canada) showing the dense herbaceous understory (Photo: N. Eisenhauer), (B) showing a bench with some of the 80 numbered and randomized experimental trays (seedling emergence experiment) under greenhouse conditions at Darmstadt University of Technology (Photo: N. Eisenhauer), (C) of Lumbricus terrestris L., a large-bodied anecic earthworm species (Photo: H. Schuy), and (D) of Octolasion tyrtaeum Savigny, a large-bodied endogeic earthworm species (Photo: H. Schuy). Both earthworm species are exotics currently invading the studied aspen forest. 
Earthworms are known to engineer seedbed conditions for plants and recent studies highlighted the importance of direct and indirect interactions between earthworms and plant seeds for plant community composition (Eisenhauer and Scheu 2008; Eisenhauer and others 2008a, 2009; Regnier and others 2008). It is increasingly recognized that after the displacement of seeds from the parent plant to the soil surface, earthworms play an important role in the subsequent displacement of seeds on the soil surface and burial into the soil (Grant 1983; Willems and Huijsmans 1994; Decaens and others 2001, 2003; Milcu and others 2006; Eisenhauer and Scheu 2008; Eisenhauer and others 2008a, b). Furthermore, earthworms affect plant seeds and seedling fates in both positive and negative ways by a number of mechanisms. They enhance seed survival by reducing exposure of seeds to aboveground seed predators (Heithaus 1981), create nutrient-rich gaps for seed germination (Milcu and others 2006; Eisenhauer and others 2008a), break seed dormancy, and increase germination and root initiation of plant seeds (Tomati and others 1988; Ayanlaja and others 2001; Eisenhauer and others 2009). However, seeds may also be buried below some critical depth where they fail to emerge (Traba and others 1998; Regnier and others 2008) and get damaged or digested during earthworm gut passage (McRill and Sagar 1973; Grant 1983; Shumway and Koide 1994; Eisenhauer and others 2009). A recent field study revealed that L.terrestris very efficiently buries plant seeds from the soil surface to deeper soil layers (Regnier and others 2008), thereby presumably decreasing the number of germinable seeds in the upper soil layers while increasing the number in deeper soil layers. However, it has been shown that both anecic and endogeic earthworm species affect the fate of plant seeds (Eisenhauer and others 2009). Although several studies focussed on the effects of exotic earthworms on the vegetation of ecosystems previously devoid of earthworms (Hale and others 2005, 2006; Frelich and others 2006; Eisenhauer and others 2007; Holdsworth and others 2007), impacts of exotic earthworms on soil seed banks of these ecosystems are unexplored. Generally, seed banks are a source for the re-establishment and recovery of plant species and function to escape unfavorable environmental conditions and seed predation (Juan and others 2006; Wellstein and others 2007). Consequently, impacts of exotic earthworms on seed banks might drive plant community composition of invaded ecosystems with important consequences for local plant diversity (Hale and others 2006; Holdsworth and others 2007).

We studied the impacts of exotic earthworms on the emergence of herbaceous plant species from the soil seed bank of the above-mentioned aspen forest. We sampled locations without the presence of L. terrestris and O. tyrtaeum, with only one of these species and with both species present. Moreover, we distinguished two soil layers $(0-8$ and $8-16 \mathrm{~cm})$ to account for the different ecology of the investigated earthworm species. We hypothesized that (1) exotic earthworms change the seedling emergence from the plant seed bank, (2) L. terrestris increases the emergence of plant seedlings from the deeper soil layer but decreases that of the upper soil layer due to plant seed burial, and (3) O. tyrtaeum decreases plant seedling emergence due the damage of plant seeds.

\section{MeTHODS}

\section{Study Site}

This study was conducted in a deciduous forest located in Kananaskis Valley in the front range of the Canadian Rocky Mountains in southwest Alberta $\left(51^{\circ} 2^{\prime} \mathrm{N}, 115^{\circ} 4^{\prime} \mathrm{W}\right)$ at about $1410 \mathrm{~m}$ above sea level. The dominating tree species in the investigated forest is trembling aspen (Populus tremuloides Michx.) interspersed with some balsam poplar individuals (Populus balsamifera L.). The understory is dense and mainly consists of herbs (for example, Aster conspicuus Lindl., Aster laevis L., Viola canadensis L., Epilobium angustifolium L., Delphinium glaucum Wats., Heracleum lanatum Michx.), roses (Rosa acicularis Lindl., Rosa woodsii Lindl.), and grasses (for example, Bromus sp., Danthonia sp., Agropyron sp.) (see Table 1 for plant species list; Figure 1A). The soil was classified as orthic gray luvisol (Karkanis 1972). The climate is characterized by long, cold winters with intermittent warm Chinook winds and short dry summers. The soil usually remains frozen from November until March. The mean annual precipitation at the study site is $625 \mathrm{~mm}$ and the mean annual temperature in the organic layer is $3.8^{\circ} \mathrm{C}$ (Mitchell 1974).

\section{Experimental Design}

The studied forest has been colonized in a patchy way by the exotic earthworm species $L$. terrestris and O. tyrtaeum (Eisenhauer and others 2007; Straube and others 2009). Locations in the forest without presence of L. terrestris and O. tyrtaeum, with only one of these species and with both species present 
Table 1. List of Herbaceous Plant Species in the Understory of the Investigated Aspen Forest and Their Classification to Plant Functional Groups

\begin{tabular}{ll}
\hline Plant species & $\begin{array}{l}\text { Plant functional } \\
\text { group }\end{array}$ \\
\hline Agropyron sp. & Grass \\
Aster conspicuus Lindl. & Herb \\
Aster laevis L. & Herb \\
Bromus sp. & Grass \\
Danthonia sp. & Grass \\
Delphinium glaucum Wats. & Herb \\
Disporum hookeri Torr. & Herb \\
Epilobium angustifolium L. & Herb \\
Fragaria virginiana Dcne. & Herb \\
Galium boreale L. & Herb \\
Heracleum lanatum Michx. & Herb \\
Lathyrus ochroleucus Hook. & Legume \\
Lonicera utahensis Wats. & Herb \\
Osmorhiza depauperata Phil. & Herb \\
Pyrola asarifolia Michx. & Herb \\
Smillacina stellata L. & Herb \\
Taraxacum officinale L. & Herb \\
Thalictrum occidentale Gray & Herb \\
Vicia americana Muhl. & Legume \\
Viola canadensis L. & Herb \\
\hline
\end{tabular}

were carefully selected. Identification of these sites was based on sampling three transects from the edge to the center of the forest to determine earthworm distribution patterns (see Straube and others 2009 for more details) and on the inspection of the locations for earthworm activity (casts and middens). We identified 20 sampling sites: 10 with presence of O. tyrtaeum and 10 without. At each of these 20 sites, two soil cores were taken: one in the center of $L$. terrestris middens (with $L$. terrestris) and another one at approximately $1 \mathrm{~m}$ away from the midden (without $L$. terrestris) to investigate the effects of $L$. terrestris presence/middens and O. tyrtaeum presence on the soil seed bank in a full factorial design $(n=40)$. The four different sampling sites did not vary significantly in total plant coverage ( $84 \pm 3 \%$; $\left.F_{3,36}=0.59, P=0.45\right)$ and in the coverage of grasses $\left(29 \pm 3 \% ; F_{3,36}=1.41, P=0.24\right)$, herbs $(77 \pm 5 \%$; $\left.F_{3,36}=2.19, \quad P=0.15\right)$, and legumes $(15 \pm 2 \%$; $F_{3,36}=2.81, P=0.11$; visual estimation of $1 \mathrm{~m}^{2}$ in intervals of $5 \%$, modified after Daubenmire 1959). Furthermore, the sites did not differ in plant species richness $\left(8.70 \pm 0.25\right.$ species $/ \mathrm{m}^{2} ; F_{3,36}=0.05, P=$ $0.82)$, in the Shannon-Wiener index $(1.93 \pm 0.03$; $\left.F_{3,36}=0.14, P=0.71\right)$ and in the evenness of the plant community $\left(0.90 \pm 0.01 ; F_{3,36}=1.38, P=\right.$ $0.25)$. Samples were taken using a metal corer $(5 \mathrm{~cm}$ in diameter, $\sim 20 \mathrm{~cm}^{2}$ ) which was driven into the soil to a depth of $16 \mathrm{~cm}$. Soil cores were separated into two layers mainly consisting of organic $(0-8 \mathrm{~cm}$, layer 1) and mineral soil material $(8-16 \mathrm{~cm}$, layer 2 ; $\sim 160 \mathrm{~cm}^{3}, \sim 155 \mathrm{~g}$ soil fresh weight; $n=80$ ), respectively. The samples were taken in September 2007 and stored at $5^{\circ} \mathrm{C}$.

\section{Seedling Emergence Experiment}

The content of viable plant seeds in the different soil cores was analyzed by the seedling emergence method (Cosyns and Hoffmann 2005; Eichberg and others 2007). In November 2007, soil samples were frozen for 2 weeks $\left(-10^{\circ} \mathrm{C}\right)$ to break seed dormancy. Then, the soil of each soil core and layer was placed in individual trays $(15 \mathrm{~cm} \times 22 \mathrm{~cm} \times$ $5 \mathrm{~cm})$ and exposed to light $\left(450-650 \mu \mathrm{E} / \mathrm{m}^{2} \mathrm{~s}\right)$ under controlled greenhouse conditions (day/night regime of $16 / 8 \mathrm{~h}$ and $20 / 10 \pm 2{ }^{\circ} \mathrm{C}$; Figure 1B). The soil was kept moist continuously. Trays were randomized weekly and emerging seedlings were identified, counted, and removed every week for 4 months. To expose seeds to light that initially were located at the bottom of the trays, the soil was mixed thoroughly every 2 weeks starting after 1 month. No further seedlings emerged 3 months after experimental start.

\section{Statistical Analyses}

Seedlings were separated to plant functional groups (total, grass, herb, and legume seedlings) due to the low emergence of single plant species. Prior to statistical analyses, the data were log-transformed to improve normality of the distribution and homogeneity of variance, if necessary. Data on the total number of established seedlings, number of grass, herb, and legumes seedlings were analyzed using fixed factor repeated measures analysis of variance (GLM) with soil layer (LAY; $0-8$ and $8-16 \mathrm{~cm}$ ) as repeated factor, and presence/middens of $L$. terrestris (LUM; center of the midden and control $\sim 1$ m away from the midden) and presence of $O$. tyrtaeum (OCT; with and without) as categorical factors $(n=80)$. Furthermore, protected analyses of variance were performed for the two single soil layers (Scheiner and Gurevitch 2001). Moreover, two-factorial ANOVAs were performed to analyze the effect of earthworm presence (LUM and OCT) on the relative number of grass, herb, and legume seedlings. Therefore, we only used samples with established plant seedlings and summed up the number of plant seedlings of layers 1 and $2(n=20)$. Furthermore, single-factor ANOVAs were performed to analyze the effect of the four different sampling sites (with and without L.terrestris and O.tyrtaeum, respectively) on the coverage of the vegetation and the 
coverage of grasses, herbs, and legumes $(n=40)$. Statistical analyses were performed using SAS V9.1 (SAS Institute Inc., Cary, USA). Means ( \pm standard error) presented in text and figures were calculated using non-transformed data.

\section{RESUlts}

Generally, the number of established seedlings per soil core was low $\left(0.80 \pm 0.14\right.$ seedlings $\left./ 160 \mathrm{~cm}^{3}\right)$. The number of total seedlings and herb seedlings were significantly higher in layer $1(0.60 \pm 0.07$ and $0.30 \pm 0.13$ seedlings $/ 160 \mathrm{~cm}^{3}$ ) than in layer 2 $\left(0.20 \pm 0.13\right.$ and $0.08 \pm 0.06$ seedlings $/ 160 \mathrm{~cm}^{3}$; Table 2, Figure 2A, C). The presence/middens of L. terrestris did not affect the number of seedlings irrespective of the plant functional group identity and soil depth (Tables 2,3). On the contrary, the number of total seedlings was increased significantly in presence of $O$. tyrtaeum $(\times 2.56$; Table 2$)$. However, this increase was only significant in layer 1 (Table 3, Figure 2A) and was due to the considerable increase of the number of grass $(\times 6.0)$ and herb seedlings $(\times 4.0)$ in the presence of 0 .tyrtaeum (Table 2). Although the number of grass seedlings was only increased significantly in layer 1 in the presence of 0 . tyrtaeum (Table 3, Figure 2B), there was a tendency of increased numbers of herb seedlings in both soil layers (Table 2, Figure 2C). However, the number of herb seedlings also depended on the presence of both earthworm species (Table 2). Although no herb seedlings established in the absence of earthworms, the number of herb seed-

Table 2. MANOVA Table of F-Values on the Effects of Earthworms and Soil Depth on the Number of Plant Seedlings

\begin{tabular}{|c|c|c|c|c|c|}
\hline & Df & Total & Grasses & Herbs & Legumes \\
\hline \multicolumn{6}{|c|}{ Between subject factors } \\
\hline LUM & 1 & 0.67 & 0.18 & 0.30 & 1.08 \\
\hline OCT & 1 & $6.74 * \uparrow$ & $4.59 * \uparrow$ & $6.86 * \uparrow$ & 0.05 \\
\hline LUM $\times$ OCT & 1 & 0.47 & 1.65 & $3.95^{*}$ & 2.82 \\
\hline Error & 36 & & & & \\
\hline \multicolumn{6}{|c|}{ Within subject factors } \\
\hline LAY & 1 & $5.36 * \downarrow$ & 0.14 & $4.14^{*} \downarrow$ & 2.33 \\
\hline $\mathrm{LAY} \times \mathrm{LUM}$ & 1 & 0.02 & 1.25 & 0.01 & 1.71 \\
\hline $\mathrm{LAY} \times \mathrm{OCT}$ & 1 & 0.66 & 1.25 & 0.46 & 0.09 \\
\hline $\begin{array}{l}\text { LAY } \times \text { LUM } \\
\times \text { OCT }\end{array}$ & 1 & 0.34 & 0.14 & 1.63 & 0.26 \\
\hline Error & \multicolumn{5}{|l|}{36} \\
\hline \multicolumn{6}{|c|}{$\begin{array}{l}\text { Significant effects }\left({ }^{*} P \leq 0.05\right) \text { are given in bold. } \\
D f=\text { degrees of freedom; } \uparrow=\text { increase (in presence of earthworms or with } \\
\text { increasing soil depth); } \downarrow=\text { decrease; LUM }=\text { Lumbricus terrestris; OCT } \\
\text { Octolasion tyrtaeum; LAY= soil layer; } 0-8 \text { and } 8-16 \mathrm{~cm} \text {. Seedling categories: } \\
\text { Total, grasses, herbs, and legumes. }\end{array}$} \\
\hline
\end{tabular}
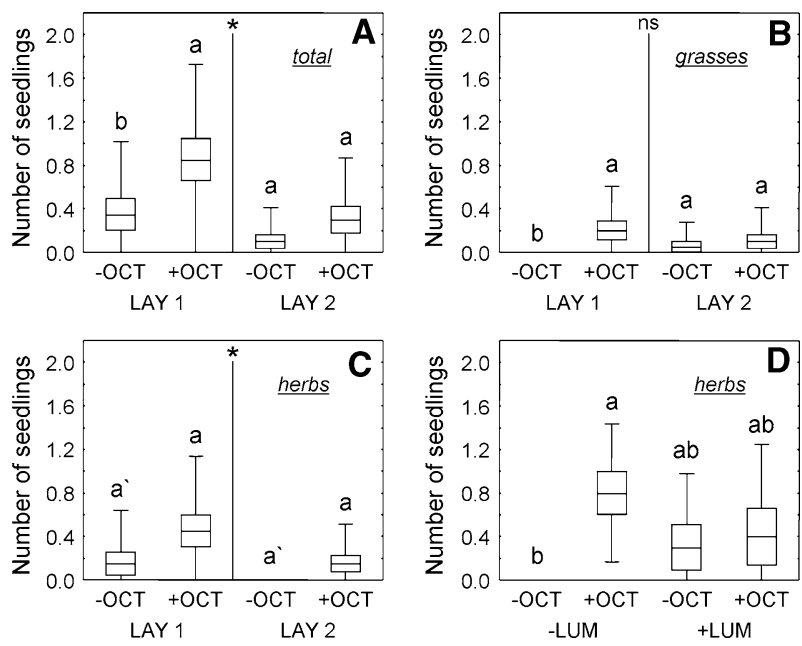

Figure 2. Variations in the number of established seedlings per soil core (diameter $5 \mathrm{~cm}$, height $8 \mathrm{~cm})(\mathbf{A}-\mathbf{C})$ as affected by presence of Octolasion tyrtaeum $(-\mathrm{OCT}=$ without and + OCT $=$ with) and soil depth (LAY $1=$ $0-8 \mathrm{~cm}$ and LAY $2=8-16 \mathrm{~cm}$ ) and (D) as affected by presence of Octolasion tyrtaeum and presence of Lumbricus terrestris $(-\mathrm{LUM}=$ without and $+\mathrm{LUM}=$ with $)$. Means with standard error (boxes) and standard deviation (error bars). Means with different letters vary significantly (Tukey's HSD test, $\alpha<0.05$ ), and asterisks indicate significant differences between soil layers $(P<0.05)$ and inverted commas virtually significant differences between means $(P<0.1)$.

lings was increased significantly in the presence of O. tyrtaeum only (Figure 2D). Remarkably, this effect disappeared in the presence of L.terrestris. Generally, the number of legume seedlings was not affected by earthworm presence and soil depth (Tables 2, 3).

Table 3. Table of F-Values of Protected ANOVAs on the Effects of Earthworms on the Number of Plant Seedlings in Two Soil Layers

\begin{tabular}{lrllll}
\hline & Df & Total & Grasses & Herbs & Legumes \\
\hline Layer 1 & & & & & \\
LUM & 1 & 0.32 & 1.20 & 0.07 & 1.77 \\
OCT & 1 & $\mathbf{3 . 9 9} \uparrow$ & $\mathbf{4 . 8 0 *}$ & $\mathbf{3 . 5 6}\left(^{*}\right)$ & 0.09 \\
LUM $\times$ OCT & 1 & 0.00 & 1.20 & $\mathbf{3 . 5 6}\left(^{*}\right)$ & 1.77 \\
Error & 36 & & & & \\
Layer 2 & & & & & \\
LUM & 1 & 0.25 & 0.33 & 0.36 & 0.00 \\
OCT & 1 & 1.66 & 0.33 & $\mathbf{3 . 2 4}(*) \uparrow$ & 0.00 \\
LUM $\times$ OCT & 1 & 1.16 & 0.33 & 0.36 & 2.00 \\
Error & 36 & & & &
\end{tabular}

Significant effects $(P \leq 0.05)$ and distinct tendencies $(P<0.1)$ are given in bold. $D f=$ degrees of freedom; $*=P \leq 0.05 ;\left({ }^{*}\right)=P<0.1 ; \uparrow=$ increase (in presence of earthworms); LUM = Lumbricus terrestris; OCT $=$ Octolasion tyrtaeum; $L A Y=$ soil layer; $0-8$ and $8-16 \mathrm{~cm}$. Seedling categories: Total, Grasses, Herbs, and Legumes. 
The proportion of grass seedlings of the total number of plant seedlings was not affected by earthworms ( $25 \pm 9 \%$; Table 4, Figure 3$)$. On the contrary, the proportions of herb $(46 \pm 11 \%)$ and legume seedlings $(29 \pm 10 \%)$ of the total number of plant seedlings were significantly affected by an interaction between the two earthworm species (Table 4). Although herb seedlings only established in the presence of earthworms (with maximum proportions of total seedlings in presence of $L$. terrestris only), the proportion of legume seedlings was considerably lower in the presence of earthworms, particularly in the sole presence of L. terrestris (Figure 3).

Table 4. ANOVA Table of $F$-Values on the Effects of Earthworms on the Proportion of the Number of Plant Seedlings Belonging to the Plant Functional Groups Grasses, Herbs, and Legumes

\begin{tabular}{|c|c|c|c|c|}
\hline & Df & Grasses & Herbs & Legumes \\
\hline LUM & 1 & 0.32 & 2.45 & $3.93(*) \downarrow$ \\
\hline OCT & 1 & 1.51 & 0.01 & 1.77 \\
\hline $\mathrm{LUM} \times \mathrm{OCT}$ & 1 & 2.63 & $17.77^{* * *}$ & $4.84^{*}$ \\
\hline Error & 17 & & & \\
\hline
\end{tabular}

Significant effects $(P \leq 0.05)$ and distinct tendencies $(P<0.1)$ are given in bold. $D f=$ degrees of freedom; $* * *=P<0.001 ; *=P<0.05 ;\left(^{*}\right)=P<0.1 ; \downarrow=$ decrease (in presence of earthworms); LUM $=$ Lumbricus terrestris; OCT $=$ Octolasion tyrtaeum.

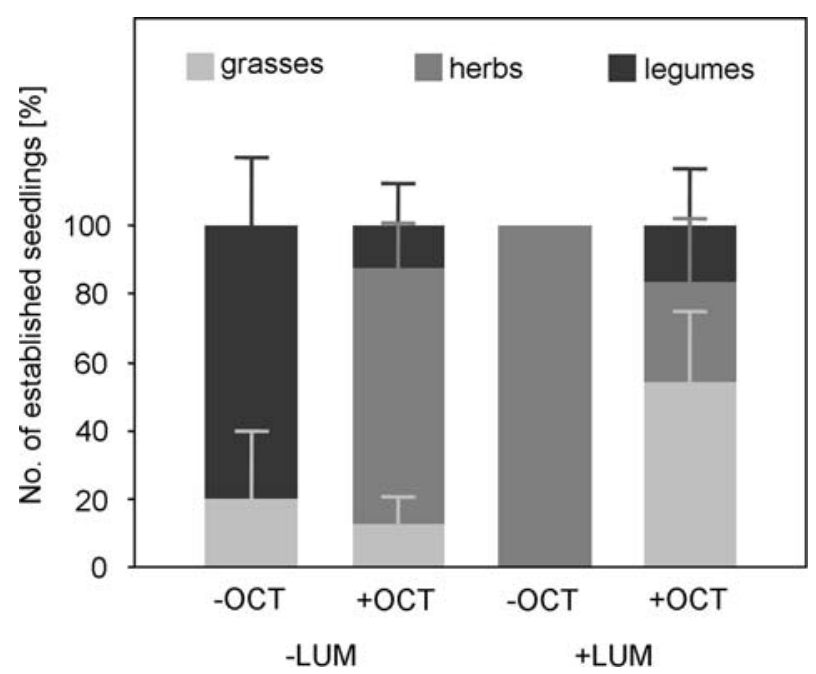

Figure 3. Variations in the proportion of the number of established seedlings belonging to the plant functional groups grasses, herbs, and legumes as affected by the presence of Lumbricus terrestris (-LUM = without and + LUM $=$ with $)$ and Octolasion tyrtaeum $(-\mathrm{OCT}=$ without and + OCT $=$ with $)$. Means with standard error.

\section{Discussion}

Exotic earthworms profoundly change above- and belowground properties of northern North American deciduous forests (Bohlen and others 2004; Hale and others 2005, 2006; Frelich and others 2006; Eisenhauer and others 2007; Holdsworth and others 2007; Straube and others 2009). By altering seedbed conditions, exotic earthworms were reported to be a threat for plant diversity of forests previously devoid of earthworms (Hale and others 2006; Holdsworth and others 2007). Conforming to hypothesis (1), this study indicates that exotic earthworms change native seed banks. Although plant species composition of the standing vegetation did not differ significantly between the four sampling sites, total seedling numbers and seedling numbers of the plant functional groups grasses, herbs, and legumes varied considerably. Thus, we assume that changes in plant seedling emergence were due to earthworm presence and not due to different characteristics of the four sampling sites. Although, the invasion of the investigated forest by L. terrestris and particularly by 0 . tyrtaeum presumably started quite recently (Eisenhauer and others 2007), changes in plant seedling emergence are likely to change plant community composition. However, in contrast to hypothesis (2), the presence/middens of L. terrestris did not affect plant seedling numbers significantly, irrespective of soil depth. Previous studies showed that this anecic earthworm species buries plant seeds efficiently (Milcu and others 2006; Eisenhauer and Scheu 2008; Eisenhauer and others 2008b) and forms nutrient-rich plant regeneration niches (Eisenhauer and Scheu 2008; Eisenhauer and others 2008a). Furthermore, L. terrestris was shown to affect plant seeds directly via ingestion and digestion of plant seeds and indirectly via breaking seed dormancy due to physical and chemical stimuli (Shumway and Koide 1994; Ayanlaja and others 2001; El Harti and others 2001; Eisenhauer and others 2009). Moreover, a recent field study highlighted that L. terrestris concentrates plant seeds in its burrows (sixfold higher concentration of seeds in burrows than in the surrounding soil) and incorporates plant seeds into deeper soil layers (0.5-22 cm deep; Regnier and others 2008). However, in contrast to hypothesis (2), seedling emergence from the deeper soil layer was not increased in the presence of L. terrestris in this study. Similarly and surprisingly, L. terrestris burrows also had little effect on soil abiotic ( $\mathrm{pH}, \mathrm{C}$, and $\mathrm{N}$ concentrations) and biotic (microbial respiration and biomass and microarthropod densities) properties in the investigated aspen forest (Straube and others 2009). 
One possible explanation for the missing L. terrestris effects may be that the earthworm burrows did not run completely vertically and, therefore, were not included in the sampled soil core $(5 \mathrm{~cm}$ in diameter) in deeper soil layers.

In contrast to $L$. terrestris, the presence of $O$.tyrtaeum affected plant seedling emergence considerably. Contrary to hypothesis (3), emergence of grass and herb seedlings from the seed bank was increased significantly in presence of this endogeic earthworm species (sixfold and fourfold increase in seedling numbers, respectively). Remarkably, this trend of increased seedling numbers was consistent for both soil layers. Obviously, positive effects of O. tyrtaeum on plant seeds, such as the physical and chemical acceleration and breakage of seed dormancy (Tomati and others 1988; Ayanlaja and others 2001; El Harti and others 2001; Eisenhauer and others 2009), were more important than negative ones, such as damaging and digesting of seeds (Grant 1983; Decaens and others 2001, 2003; Eisenhauer and others 2009). However, interactions between earthworms and grassland plant seeds were shown to be species specific and idiosyncratic (Eisenhauer and others 2009). Results of this study underline previous observations by showing increased numbers of herb seedlings in the presence of O. tyrtaeum. This increase was particularly pronounced for the most abundant herb species A. leavis (not shown); interestingly, coverage of this species was positively correlated with the density of O. tyrtaeum in 2004 (Eisenhauer and others 2007). Thus, certain plant species, such as A. leavis, might benefit from the presence of exotic earthworms at the expense of other species. However, this topic deserves further attention.

Results of this study suggest that the functional composition of emerging plants and, therefore, of the whole plant community is altered by exotic earthworms. Earthworm presence enhanced the emergence of herb seedlings but decreased the proportion of legume seedlings. Remarkably, only herb seedlings emerged in the presence of L. terrestris only. Again, this underlines observations from 2004 showing that shoot biomass of grasses and legumes declined at a higher density of $L$. terrestris (Eisenhauer and others 2007). These differences in earthworm impacts on plant seedling emergence of certain plant functional groups might have been due to variations in seed coat morphology. Previous studies suggested that slight physical and chemical damage to plant seed coats by earthworms breaks seed dormancy and enhances plant germination (Tomati and others 1988; Ayanlaja and others 2001; Eisenhauer and others 2009). In contrast to the majority of grass and herb species, both legume species occurring in the investigated aspen forest (Vicia americana Muhl. and Lathyrus ochroleucus Hook.) have thick seed coats that probably were not affected by earthworms. However, for example, the seed coat of the herb species A. leavis is comparatively thin allowing for strong $O$. tyrtaeum effects. Thus, the number of emerging legume seedlings was not affected by earthworms inducing lower proportions of legume seedlings of the total number of plant seedlings in the presence of earthworms. These results indicate that effects of exotic earthworms on the plant community composition of invaded forests are not only due to changes in seedbed conditions, for example, soil structure and nutrient availability, but also due to interactions between earthworms and plant seeds and, therefore, alterations in plant recruitment.

\section{ConClusions}

This study shows for the first time that exotic earthworms alter the seedling emergence from forest seed banks and the functional composition of the established plant seedlings. Surprisingly, L. terrestris only marginally affected seedling emergence, whereas $O$. tyrtaeum strongly increased the emergence of native plant species from the seed bank. However, earthworm impacts depended on the plant functional group; particularly herb species benefited, whereas legumes suffered from the presence of exotic earthworms. This highlights the strong effects of invasive belowground ecosystem engineers on aboveground ecosystem characteristics and foreshadows fundamental changes of native ecosystems by human-spread earthworm species.

\section{ACKNOWLEDGMENTS}

We thank Suzanne Visser (University of Calgary), Judy Buchanan-Mappin, Mike Mappin, Gary Wainwright, Andrew Lodge (Barrier Lake Field Station), Carsten Eichberg, and Angelika Schwabe-Kratochwil (Darmstadt University of Technology) for the support during soil sampling and the plant seedling emergence experiment. Furthermore, we thank two anonymous referees for their helpful critique which helped to improve the manuscript.

\section{OPEN ACCESS}

This article is distributed under the terms of the Creative Commons Attribution Noncommercial License which permits any noncommercial use, distribution, and reproduction in any medium, provided the original author(s) and source are credited. 


\section{REFERENCES}

Addison JA. 2009. Distribution and impacts of invasive earthworms in Canadian forest ecosystems. Biol Invasions 1 1:59-79.

Anderson CB, Rosemond AD. 2007. Ecosystem engineering by invasive exotic beavers reduces in-stream diversity and enhances ecosystem function in Cape Horn, Chile. Oecologia 154: 141-53.

Ayanlaja SA, Owa SO, Adigun MO, Senjobi BA, Olaleye AO. 2001. Leachate from earthworm castings breaks seed dormancy and preferentially promotes radicle growth in jute. Hortscience 36 : $143-4$.

Bohlen PJ, Scheu S, Hale CM, McLean MA, Groffman PM, Parkinson D. 2004. Non-native invasive earthworms as agents of change in northern temperate forests. Front Ecol Environ 2: 427-35.

Cosyns E, Hoffmann M. 2005. Horse dung germinable seed content in relation to plant species abundance, diet composition and seed characteristics. Basic Appl Ecol 6:11-24.

Cuddington K, Hastings A. 2004. Invasive engineers. Ecol Model 178:335-47.

Daubenmire RF. 1959. Canopy coverage method of vegetation analysis. Northwest Sci 33:43-64.

Decaens T, Mariani L, Betancourt N, Jimenez JJ. 2001. Earthworm effects on permanent soil seed banks in Colombian grasslands. In: Jimenez JJ, Thomas RJ, Eds. Nature's plow: soil macroinvertebrate communities in the neotropical savannas of Colombia. Colombia: CIAT. p 174-293.

Decaens T, Mariani L, Betancourt N, Jimenez JJ. 2003. Seed dispersion by surface casting activities of earthworms in Colombian grasslands. Acta Oecol 24:175-85.

Edwards CA. 2004. Earthworm ecology. 2nd edn. Boca Raton (FL): CRC Press, 441 pp.

Eichberg C, Storm C, Schwabe A. 2007. Endozoochorous dispersal, seedling emergence and fruiting success in disturbed and undisturbed successional stages of sheep-grazed inland sand ecosystems. Flora 202:3-26.

Eisenhauer N, Partsch S, Parkinson D, Scheu S. 2007. Invasion of a deciduous forest by earthworms: changes in soil chemistry, microflora, microarthropods and vegetation. Soil Biol Biochem 39:1099-110.

Eisenhauer N, Scheu S. 2008. Invasibility of experimental grassland communities: the role of earthworms, plant functional group identity and seed size. Oikos 117:1026-36.

Eisenhauer N, Milcu A, Sabais ACW, Scheu S. 2008a. Animal ecosystem engineers modulate the diversity-invasibility relationship. PLOS ONE 3:e3489.

Eisenhauer N, Marhan S, Scheu S. 2008b. Assessment of anecic behavior in selected earthworm species: effects on wheat seed burial, seedling establishment, wheat growth and litter incorporation. Appl Soil Ecol 38:79-82.

Eisenhauer N, Schuy M, Butenschoen O, Scheu S. 2009. Direct and indirect effects of endogeic earthworms on plant seeds. Pedobiologia 52:151-62.

El Harti A, Saghi M, Molina J-AE, Teller G. 2001. Production de composés rhizogènes par le ver de terre Lumbricus terrestris. Can J Zool 79:1921-32.

Frelich LE, Hale CM, Scheu S, Holdsworth AR, Heneghan L, Bohlen PJ, Reich PB. 2006. Earthworm invasion into previously earthworm-free temperate and boreal forests. Biol Invasions 8:1235-45.
Gates GE. 1982. Farewell to North American megadriles. Megadrilogica 4:12-77.

Grant JD. 1983. The activities of earthworms and the fates of seeds. In: Satchell JE, Ed. Earthworm ecology: from Darwin to vermiculture. London: Chapman and Hall, pp 107-22.

Groffman PM, Bohlen PJ, Fisk MC, Fahey TJ. 2004. Exotic earthworm invasion and microbial biomass in temperate forest soils. Ecosystems 7:45-54.

Hale CM, Frelich LE, Reich PB, Pastor J. 2005. Effects of European earthworm invasion on soil characteristics in northern hardwood forests of Minnesota, USA. Ecosystems 8:911-27.

Hale CM, Frelich LE, Reich PB. 2006. Changes in hardwood forest understory plant communities in response to European earthworm invasions. Ecology 87:1637-49.

Hale CM, Frelich LE, Reich PB, Pastor J. 2008. Exotic earthworm effects on hardwood forest floor, nutrient availability and native plants: a mesocosm study. Oecologia 155:509-18.

Heithaus ER. 1981. Seed predation by rodents on three antdispersed plants. Ecology 62:135-45.

Holdsworth AR, Frelich LE, Reich PB. 2007. Effects of earthworm invasion on plant species richness in northern hardwood forests. Conserv Biol 21:997-1008.

Jones CG, Lawton JH, Shachak M. 1994. Organisms as ecosystem engineers. Oikos 69:373-86.

Juan T, Azcárate FM, Peco B. 2006. The fate of seeds in Mediterranean soil seed banks in relation to their traits. J Veg Sci 17:5-10.

Karkanis PG. 1972. Soils of the Kananaskis Valley. Research Report 1. Environmental Science Centre, University of Alberta, Calgary

Lavelle P, Pashanasi B, Charpentier F, Gilot C, Rossi J-P, Derouard L, Andre J, Ponge J-F, Bernier F. 1998. Large-scale effects of earthworms on soil organic matter and nutrient dynamics. In: Edwards CA, Ed. Earthworm ecology. 2nd edn. Boca Raton (FL): CRC Press, pp 103-22.

Lee KE. 1985. Earthworms: their ecology and relationships with soils and land use. Sydney: Academic Press.

McKey-Fender D, Fender WM. 1982. Arctiostrots (gen nov.) Part I. The identity of Plutellus perrieri Benham, 1892 and its relation to glacial refugia. Megadrilogica 4:81-5.

McRill M, Sagar GR. 1973. Earthworms and seeds. Nature 243: 482.

Migge-Kleian S, McLean MA, Maerz JC, Heneghan L. 2006. The influence of invasive earthworms on indigenous fauna in ecosystems previously uninhabited by earthworms. Biol Invasions 8:1275-85.

Milcu A, Schumacher J, Scheu S. 2006. Earthworms (Lumbricus terrestris) affect plant seedling recruitment and microhabitat heterogeneity. Funct Ecol 20:261-8.

Mitchell KJ. 1974. Ecology of oribatid mites (Acari: Cryptostigmata) in an aspen woodland soil. DS thesis, University of Calgary.

Morrison LW. 2002. Long-term impacts of an arthropod-community invasion by the imported fire ant, Solenopsis invicta. Ecology 83:2337-45.

Regnier E, Harrison SK, Liu J, Schmoll JT, Edwards CA, Arancon N, Holloman C. 2008. Impact of an exotic earthworm on seed dispersal of an indigenous US weed. J Appl Ecol 45:1621-9.

Scheiner SM, Gurevitch J. 2001. Design and analysis of ecological experiments. 2nd edn. New York: Oxford University Press. 
Scheu S, McLean MA. 1993. The earthworm (Lumbricidae) distribution in Alberta (Canada). Megadrilogica 4:175-80.

Shumway DL, Koide RT. 1994. Seed preferences of Lumbricus terrestris L. Appl Soil Ecol 1:11-5.

Straube D, Johnson EA, Parkinson D, Scheu S, Eisenhauer N. 2009. Nonlinearity of effects of invasive ecosystem engineers on abiotic soil properties and soil biota. Oikos 118:885-96.

Tomati U, Grappelli A, Galli E. 1988. The hormone-like effect of earthworm casts on plant growth. Biol Fertil Soils 5:288-94.

Traba J, Levassor C, Peco B. 1998. From what depth do seeds emerge? A soil seed bank function experiment in Mediterranean grasslands. Seed Sci Res 14:297-303.
Vitousek PM, D'Antonio CM, Loope LL, Westbrooks R. 1996. Biological invasions as global environmental change. Am Sci 8:468-78.

Vitousek PM, Mooney HA, Lubchenco J, Melillo JM. 1997. Human domination of Earth's ecosystems. Science 277:494-9.

Wellstein C, Otte A, Waldhardt R. 2007. Seed bank diversity in mesic grasslands in relation to vegetation type, management and site conditions. J Veg Sci 18:153-62.

Willems JH, Huijsmans KGA. 1994. Vertical seed dispersal by earthworms: a quantitative approach. Ecography 17:124-30. 